\title{
DDAVP and urine osmolality in refractory enuresis
}

\section{S B DIMSON}

Special Investigation Clinic, Woolwich, London

SUMmARY A double blind crossover trial of $20 \mu \mathrm{g}$ intranasal 1-deamino-8-D-arginine vasopressin (DDAVP) versus placebo was carried out in 17 children with intractable enuresis aged between 6 and 13 years who had failed to respond to drugs and an enuresis alarm. Fluid intake was not restricted. There was a significant reduction in the number of wet nights. Seven children $(41 \%)$ were cured or showed considerable improvement, with strong evidence against any placebo effect. The best response was seen in children aged 10 years or over and if urine osmolality after DDAVP reached beyond $1000 \mathrm{mmol} / \mathrm{kg}$ or was already at this concentration. The degree of overnight rise in urine osmolality after treatment with DDAVP was not predictable but correlated well with the clinical improvement in nocturnal diuresis present in eight of the children.

A further 12 children with equally refractory enuresis were given $20 \mu \mathrm{g}$ of the active drug to take during their school journeys or holidays. Six of them had previously normal overnight urine osmolalities with only two successes, but of the six who had nocturnal diuresis before treatment, five became dry, suggesting that DDAVP acts largely by anti-diuresis and might be most useful in children with nocturnal polyuria.

Intranasal 1-deamino-8-D-arginine vasopressin (DDAVP), the synthetic analogue of vasopressin, is the treatment of choice for diabetes insipidus that is sensitive to vasopressin because it has a prolonged anti-diuretic action dependent on dose with no side effects $^{12}$ nor inhibition of growth hormone, prolactin, or cortisol at night in children. ${ }^{2}$

Could nocturnal enuresis be helped by this antidiuresis? In a pilot study $10 \mu \mathrm{g}$ of intranasal DDAVP was effective in 11 of 20 children with resistant enuresis. ${ }^{3}$ This was confirmed with $10-40$ $\mu \mathrm{g}$ both in controlled studies ${ }^{4-6}$ and double blind clinical trials, ${ }^{7-12}$ with but one dissent. ${ }^{13}$ But in many of these studies an enuresis alarm (the 'buzzer') had never been used and the degree of enuresis was not severe. In diabetes insipidus there is a consistent and considerable rise in urine osmolality after treatment with DDAVP, but there has been no such detailed study of this topic in enuresis. A double blind trial with crossover was therefore designed not only to determine the value of $20 \mu \mathrm{g}$ DDAVP in enuresis refractory to conventional treatment, including the buzzer, but more importantly to see whether a rise in urine osmolality was a necessary factor in any success achieved.

\section{Patients and methods}

Some 200 children attend a community health enuretic clinic in Woolwich (south east London). Seventeen (14 boys and three girls) between the ages of 6 and 13 years were selected because, like those in the pilot study, they had failed to respond to treatment with drugs (mainly imipramine and amitriptyline) and the buzzer over a mean period of two years. Eight had been wet every night (many twice or more), but two had once been dry between 2 and $3 \frac{1}{2} / 4$ years of age. Informed consent was obtained from their mothers. Children were excluded from the trial if they had more dry nights than wet in the observation period of two weeks or if they had a urinary infection or showed any clinical or radiological evidence of organic disease. As with all children with enuresis their homes had been visited by a social worker, usually the one attached to the clinic, who found that 10 , including three with secondary soiling, came from broken homes. Most were psychologically disturbed.

Every child was allocated randomly to take intranasally either $20 \mu \mathrm{g}$ DDAVP or a seemingly identical placebo. Neither the parent nor the doctor knew the code. The clinic sister patiently showed each child how to blow the liquid up his nose using a graduated plastic tube (rhinyle). At each bedtime, for two weeks, the bladder was emptied and the liquid instilled. This was immediately followed for the next fortnight by the other solution. After each period the child had to produce his empty phial. No 
other treatment was given during the trial and fluids were not limited. The number of wet and dry nights were charted for each period. The first urine sample to be tested for osmolality was passed in the afternoon at the clinic immediately before the trial and the second and third were collected after each fortnightly period on waking. Urine osmolality was determined by depression of the freezing point using an MSE osmometer (maximum reading $1400 \mathrm{mmol} /$ $\mathrm{kg}$ ). Weight and blood pressure were measured before the trial and at the end of each period. The child was also weighed at school between clinic visits. Serum osmolality was not estimated because venepuncture was considered a 'minimal risk procedure'. Unless otherwise indicated, the results were analysed by the Fisher exact single tail method.

\section{Results}

Clinical. There were no side effects and there was no clinical evidence of overhydration and no significant change in blood pressure or body weight.

Overall, treatment with DDAVP produced a significant clinical improvement, with 117 wet nights in two weeks against 169 on placebo $(\mathrm{p}<0.02$ by the Wilcoxon method for ranked paired data). Two children showed complete cure during the treatment with DDAVP (all nights dry), five were greatly improved (at least five dry nights a week), five were slightly improved (averaging three dry nights a week, one night more than with placebo), and five were failures, including three who became dry at the mother's bedtime and were less 'soaked' by morning. Thus treatment with DDAVP was successful in seven of the 17 children $(41 \%)$. That these successes might have been due to a placebo effect was unlikely because there were no successes on placebo, only five improving slightly and the remainder being failures. Moreover, when the placebo was given first (10 cases) all but two (who failed clinically) of the children showed greater improvement when subsequently treated with DDAVP, whereas when the active drug was given first (seven cases) treatment with placebo showed greater improvement in only two (who were also failures).

No significant difference was found between children from intact and broken homes or between those who had and had not been wet every night. Older children, however, fared better than younger ones, with four successes in the six who were aged 10 years or more (56 dry nights in two weeks, mean $9 \cdot 3$ ) but only three in the 11 aged less than 10 (55 dry nights in two weeks, mean 5.9) $\left(\chi^{2}=12.05\right.$, $\mathrm{p}<0.001$ ).

Urine osmolality. The range of overnight urine osmolality in normal children is $873-1305 \mathrm{mmol} /$ kg. ${ }^{14}$ Osmolality was increased by treatment with DDAVP in all but five of the children. There was a clear and significant relation between osmolality and clinical response (Table 1). The best results were achieved if overnight urine osmolality after treatment with DDAVP increased beyond $1000 \mathrm{mmol} / \mathrm{kg}$ or if it was already at this concentration after treatment with placebo, which allowed little room for a further increase (four cases, comprising three successes and one failure). If urine osmolality failed to reach $1000 \mathrm{mmol} / \mathrm{kg}$, however, results with one exception were poor $(\mathrm{p}<0.005)$.

There were eight presumed cases of nocturnal water diuresis, who had an overnight urine osmolality of $250-505 \mathrm{mmol} / \mathrm{kg}$, in contrast to the remaining nine, whose range was $745-1143 \mathrm{mmol} / \mathrm{kg}$ (Table 2).

Table 1 Clinical results and concentrations of overnight urine osmolality reached after treatment with DDAVP

\begin{tabular}{|c|c|c|c|c|c|}
\hline \multirow{2}{*}{$\begin{array}{l}\text { Urine } \\
\text { osmolality } \\
\text { after DDAVP } \\
\text { (mmol/kg) }\end{array}$} & \multicolumn{2}{|c|}{ Successes } & \multicolumn{2}{|l|}{ Failures } & \multirow{2}{*}{$\begin{array}{l}\text { Total } \\
\text { successes }\end{array}$} \\
\hline & $\begin{array}{l}\text { All } \\
d r y\end{array}$ & $\begin{array}{l}\text { Greatly } \\
\text { improved }\end{array}$ & $\begin{array}{l}\text { Slightly } \\
\text { improved }\end{array}$ & $\begin{array}{l}\text { All } \\
\text { wet }\end{array}$ & \\
\hline $\begin{array}{c}1041-1348 \\
857-961 \\
605-733 \\
240-373\end{array}$ & 2 & $\begin{array}{l}4 \\
1\end{array}$ & $\begin{array}{l}- \\
2 \\
2\end{array}$ & $\left.\begin{array}{l}2 \\
1 \\
1 \\
2\end{array}\right\}$ & $\begin{array}{l}6 / 8 \\
1 / 9\end{array}$ \\
\hline Total & 2 & 5 & 4 & 6 & $7 / 17$ \\
\hline
\end{tabular}

Table 2 Overnight urine osmolalities ( $m m o l / k g$ ) after treatment with placebo or DDAVP compared with afternoon osmolalities before trial

\begin{tabular}{|c|c|c|c|c|}
\hline & \multicolumn{3}{|c|}{ Urine osmolalities } & \multirow[t]{2}{*}{ Results } \\
\hline & $\begin{array}{l}\text { After } \\
\text { placebo }\end{array}$ & $\begin{array}{l}\text { After } \\
D D A V P\end{array}$ & Afternoon & \\
\hline $\begin{array}{l}\text { No } \\
\text { nocturnal } \\
\text { diuresis }\end{array}$ & $\begin{array}{r}1190 \\
1143 \\
1086 \\
1004 \\
920 \\
866 \\
841 \\
841 \\
745\end{array}$ & $\begin{array}{r}1112 \\
1348 \\
1041 \\
1146 \\
961 \\
1050 \\
1019 \\
733 \\
676\end{array}$ & $\begin{array}{r}1084 \\
980 \\
1051 \\
911 \\
962 \\
1030 \\
1077 \\
837 \\
458\end{array}$ & $\begin{array}{l}\text { Great improvement } \\
\text { Cure } \\
\text { Great improvement } \\
\text { No improvement } \\
\text { Slight improvement } \\
\text { No improvement } \\
\text { Cure } \\
\text { Slight improvement } \\
\text { Slight improvement }\end{array}$ \\
\hline $\begin{array}{l}\text { Nocturnal } \\
\text { diuresis }\end{array}$ & $\begin{array}{l}505 \\
498 \\
387 \\
330 \\
325 \\
310 \\
269 \\
250\end{array}$ & $\begin{array}{r}605 \\
1049 \\
880 \\
857 \\
240 \\
373 \\
642 \\
1044\end{array}$ & $\begin{array}{r}920 \\
1167 \\
1098 \\
316 \\
817 \\
491 \\
704 \\
966\end{array}$ & $\begin{array}{l}\text { No improvement } \\
\text { Great improvement } \\
\text { Slight improvement } \\
\text { No improvement } \\
\text { No improvement } \\
\text { No improvement } \\
\text { Great improvement } \\
\text { Great improvement }\end{array}$ \\
\hline
\end{tabular}


Clinical results were good in three and four children from these two groups, respectively, but the five with nocturnal diuresis who gave poor results included two whose osmolalities were virtually unchanged after the drug from a base so low (310 and $325 \mathrm{mmol} / \mathrm{kg}$, respectively, after placebo) that either DDAVP was not taken or not absorbed or else tubular function was so impaired by gross polydipsia as to render the drug useless. One of these two children was admitted to hospital for investigation and treatment with DDAVP; no abnormality was discovered and he was dry three nights out of four when receiving DDAVP so that it is probable that he was not taking it at home.

The most likely cause of nocturnal diuresis is compulsive drinking on the previous evening. This hypothesis is supported by the finding (Table 2) that in all eight cases the osmolalities in the afternoon before the trial began averaged $131 \%$ higher than that recorded in the urine specimens taken the first morning after placebo; this compares with only $2.5 \%$ higher in the nine cases in whom nocturia was absent.

Subsequent experience It was found that those who responded to treatment with DDAVP did so very quickly but relapsed when it was stopped. Its appropriate use would therefore apply to urgent situations such as school journeys and holidays. ${ }^{3}$ During the three years since this trial was completed, therefore, 12 more children aged between 7 and 13 years with equally refractory enuresis have been given $20 \mu \mathrm{g}$ DDAVP to take on such occasions. Before departure, overnight urine osmolalities were normal in six, but in the other six they were abnormally low $(\leqslant 651 \mathrm{mmol} / \mathrm{kg})$. Success was achieved in seven of the $12(58 \%)$, five with nocturnal diuresis but only two with normal osmolalities. Four of the five successes with nocturnal diuresis were so delighted that they asked for DDAVP again for the same purpose (one had it three times and two twice) with the same improvement on each occasion, even though they relapsed soon afterwards. It was not practicable to estimate urine osmolality immediately after their return, but it is suggested that any benefit obtained was due to anti-diuresis.

\section{Discussion}

This double blind crossover trial shows the efficacy and safety of treatment with $20 \mu \mathrm{g}$ DDAVP even in patients with intractable nocturnal enuresis, all of whom had failed to respond to drugs and the buzzer. Considerable improvement was obtained in almost half of these children (41\%), with substantial evidence against a placebo effect. This overall figure does not differentiate, however, between the children with and without nocturnal polyuria. This distinction is admittedly based on only three tests of urine osmolality on different days but it proved impracticable to do more in a busy clinic remote from the local laboratory. This limitation, however, should not invalidate the overall conclusions.

Eight of these 17 children probably had nocturnal diuresis, given their low overnight urine osmolality $(<505 \mathrm{mmol} / \mathrm{kg}$ ) on placebo, which possibly correlated with compulsive drinking on the previous evening because of the significant difference between the fairly high urine osmolalities on the afternoon before the trial began and the low readings in the first morning urine samples after treatment with placebo. Such nocturnal polyuria was found in $27 \%$ of 240 unselected children with enuresis at this clinic (unpublished observation), in each of six children studied by Birkasova et al ${ }^{7}$ and in six of 11 children with enuresis who all showed abnormally low plasma anti-diuretic hormone concentrations during the night. ${ }^{15}$

In the present trial DDAVP seemed to be of equal value in cases with and without nocturnal diuresis, but only if the two failures with very low osmolalities after treatment with both drug and placebo are included.

Mode of action. Urine osmolality of over 1000 $\mathrm{mmol} / \mathrm{kg}$ was a clear predictor of clinical efficacy. In the absence of nocturnal diuresis, however, the clinical failure in two children, despite a rise in osmolality of $14 \%$ and $21 \%$, respectively, to this figure and the great improvement obtained without any rise at all in another two (Table 2), suggests that some other factor besides anti-diuresis may occasionally also be involved, such as improved memory and learning. ${ }^{9}$ Nevertheless, a recent study supported anti-diuresis as the sole mechanism as treatment with DDAVP increased urine osmolality significantly, although no details were given. ${ }^{16}$

Some of the poor results may have been due to failure to take the drug or to inadequate absorption either from nasal congestion ${ }^{11} 12$ or faulty technique, especially in younger children, some of whom felt fluid in the pharynx with consequent loss (one child said it 'tasted horrid'). The significantly better results in older children found in this and other series ${ }^{910}$ may be attributed to better motivation and compliance with the technique, which, if not properly followed, would mean that an inadequate dose would be absorbed. It has been shown that the lower the dose the smaller and earlier the peak, ${ }^{2}$ which is normally attained four to eight hours after an intake of $20 \mu \mathrm{g},{ }^{1}$ so that some children are wet only after 
midnight. Another but rare cause for failure is gross polydipsia, which alone ${ }^{17}$ or combined with emotional stress ${ }^{18}$ may inhibit the release of anti-diuretic hormone during the night when it normally increases by up to $140 \% ;{ }^{19}$ the resultant transient nephrogenic diabetes insipidus cannot then respond to DDAVP. Such a cause could not be established in any child in this series.

Naturally, in any individual the degree of compulsive polydipsia, presumably psychogenic, is impossible to quantify as it is so often surreptitious. But even without polydipsia, nocturnal concentrations of anti-diuretic hormone have been found to be fairly low in children with enuresis ${ }^{15}$ but sufficient to allow urinary output to exceed the functional capacity of the bladder. Unfortunately, DDAVP was not used in that study, but if low anti-diuretic hormone concentrations can be confirmed DDAVP might be regarded as replacement therapy.

Further study of the interaction between DDAVP, severe enuresis, nocturia, and compulsive polydipsia with larger numbers seems highly desirable.

My sincere thanks are due to Professor O W Wrong for his valuable comments on the original manuscript; to Dr $\mathrm{P} \mathrm{O}^{\circ}$ Gorman and his staff at the Brook General Hospital for the osmolality tests; to Sister Margaret Longhurst for teaching the technique to the children and for her enthusiastic cooperation; to Mrs Sue Howells for her expert social reports; and to Dr Brian Donovan (Ferring Pharmaceuticals) for suggesting the trial and supplying the DDAVP and placebo.

\section{References}

${ }^{1}$ Edwards CRW, Kitau MJ, Chard T, Besser GM. Vasopressin analogue DDAVP in diabetes insipidus; clinical and laboratory studies. Br Med $J$ 1973;iii:375-8.

2 Becker DJ, Foley TP Jr. 1-Deamino-8-D-arginine vasopressin in the treatment of central diabetes insipidus in childhood. J Pediatr 1978;92:1011-5.
${ }^{3}$ Dimson SB. Desmopressin as a treatment for enuresis. Lancet $1977 ; \mathbf{i}: 1260$.

${ }^{4}$ Cuoghi D, Bottone U, Barbolini U, Valutazione clinicostatistica della attivita della desmopressina (DDAVP) nel trattamento dell'enuresi. Pediatria Oggi 1981;i:479-85.

5 Segmi G, Salvaggio E, Parenti D, et al. Nuova prospettiva terapeutica nell'enuresi: la desmopressina (DDAVP). Minerva Pediatr 1982;34:45-52.

${ }^{6}$ Bernasconi S, Monti G. Use of DDAVP in primary nocturnal enuresis. Minerva Pediatr 1982;34:131-4.

7 Birkasova M, Birkas I, Flynn MJ, Cort JH. Desmopressin in the management of nocturnal enuresis in children: a double-blind study. Pediatrics 1978;62:970-4.

${ }^{8}$ Tuvemo T. DDAVP in childhood nocturnal enuresis. Acta Paediatr Scand 1978;67:753-5.

9 Aladjem M, Wohl R, Baichis H, Orda S, Lotan D, Freedman S. Desmopressin in nocturnal enuresis. Arch Dis Child 1982; 57:137-9.

${ }^{10}$ Post EM, Richman RA, Blackett PR, Duncan KP, Miller K. Desmopressin response of enuretic children. Am J Dis Child 1983;137:962-3.

11 Terho P, Kekomaki M. Management of nocturnal enuresis with a vasopressin analogue $J$ Urol 1984;131:925-7.

12 Pedersen PS, Hejl M, Kjoller SS. Desamino-D-arginine vasopressin in childhood nocturnal enuresis. $J$ Urol 1985;133:65-6.

13 Ferrie BG, MacFarlane J, Glen ES. DDAVP in young enuretic patients: a double-blind trial. Br J Urol 1984;56:376-8.

14 Edelmann CM, Barnett HL, Stark H, et al. Standardised test of renal concentrating capacity in children. Am J Dis Child 1967;114:639-44.

15 Nørgaard JP, Pedersen EB, Djurhuus JC. Diurnal anti-diuretic hormone levels in enuretics. J Urol 1985;134:1029-31.

16 Wille S. Comparison of desmopressin and enuresis alarm for nocturnal enuresis. Arch Dis Child 1986;61:30-3.

17 Fourman P, Leeson PM. Thirst and polyuria. Lancet 1959;i: 268-71.

18 Barlow ED, de Wardener HE. Compulsive water drinking. $Q J$ Med 1959;28:235-58.

19 George PLG, Messerli FH, Genest J, et al. Diurnal variations of plasma vasopressin in man. J Clin Endocrinol Metab 1975; 41:332-8.

Correspondence to Dr S B Dimson, Flat 16, Hinton Wood, 17 Grove Road, Bournemouth, Dorset BH1 3DZ, England.

Received 13 June 1986 